\title{
Influence of Silica Fume on the Performance of Moderately Weathered Phonolite Concrete
}

\author{
Xiaowei $\mathrm{Wu}^{1, *}$, Zhaoxi Tang ${ }^{2}$ \\ ${ }^{1}$ CCCC Highway Consultants CO.,Ltd. Beijing 100088, China \\ ${ }^{2}$ CCCC Fourth Harbour Engineering Co.,Ltd., Guangzhou 510220, China
}

\begin{abstract}
The effect of silica fume on the performance, mechanical properties, durability and air tightness of airtight concrete was studied. The results showed that with the increase of silica fume content, the concrete performance will decrease, the compressive strength of airtight concrete will increase first, and reach the highest when the silica fume content was $8 \%$, and then it will decrease gradually. With the increase of silica fume content, the corrosion resistance coefficient of concrete increased gradually, then decreased. The permeability coefficient of concrete decreases with the increase of silica fume content, and the air tightness of concrete was improved obviously; In the project, it was advisable to use silica fume to prepare airtight concrete, and the amount of silica fume should be controlled at $4 \%-8 \%$.
\end{abstract}

\section{Introduction}

The main line of the Kenya Nairobi Expressway Project has a total length of $27 \mathrm{~km}$ and a design speed of 80 kilometres per hour. It is a national highway A-class highway with asphalt concrete pavement. The $15.710 \mathrm{~km}$ front of the main line is mainly subgrade, and the rear $11.421 \mathrm{~km}$ is mainly bridge. Except for the two-way sixlane roadbed standard width of $28.6 \mathrm{~m}$ in the east ring to the south ring road, the remaining road sections adopt the two-way four-lane $21.6 \mathrm{~m}$ wide A-class road standard. Rocks in Nairobi and the surrounding areas are dominated by igneous rocks, of which medium weathered sonic rock accounts for a relatively large proportion. Only sonic rock is available around the project. Other rock quarries are far away and costly, and the surrounding sonic rock has problems such as high water absorption and poor solidity [1,2].

The high water absorption rate and poor firmness of aggregate have certain negative effects on the performance of concrete, such as reducing concrete slump and rapid slump loss, resulting in relatively poor mechanical properties of concrete and poor frost resistance [3-7]. For this reason, many scholars have studied to improve the performance of this type of aggregate in the preparation of concrete. The main measures were aggregate pre-wetting treatment, aggregate surface shelling technology, the surface of the aggregate was impregnated with organic hydrophobic materials, and the surface of the aggregate was reinforced with carbon dioxide [8-12]. Referring to the current research results, this paper used higher activity silica fume as a mineral admixture to replace conventional admixtures to study the improvement of the performance of moderately weathered phonolite concrete and promote the application of moderately weathered phonolite in engineering.

\section{Materials and methods}

\subsection{Raw materials}

(1) Cement: P.O 42.5 ordinary Portland cement and its properties were shown in Table 1.

(2) Fly ash: II grade fly ash was used, and its fineness is $18.1 \%$, water demand ratio was $101.3 \%$, activity index in $7 \mathrm{~d}$ was $75.9 \%$ and in $28 \mathrm{~d}$ was $78.5 \%$.

(3) Silica fume: the used silica fume has a silica content of $92.5 \%$, a loss on ignition of $1.2 \%$, a water demand ratio of $121.5 \%$, a specific surface area of 16.8 $\mathrm{m} 2 / \mathrm{g}$, and a $7 \mathrm{~d}$ activity index of $116 \%$.

(4) Fine aggregate: the fine aggregate is the second zone medium sand with a fineness modulus of 2.6.

(5) Coarse aggregate: the coarse aggregate is processed from Kenyan weathered phonolite, with a continuous gradation of $5-20 \mathrm{~mm}$, and the specific technical indicators are shown in Table 2.

(6) Water-reducing agent: the polycarboxylic acidbased high-performance water-reducing agent was used, and its water-reducing rate is $27.5 \%$ and gas content is $3.1 \%$.

\subsection{Mix proportion}

In order to experimentally study the influence of silica fume on the properties of moderately weathered phonolite concrete, the concrete mix proportion was designed. The amount of cementitious material was

\footnotetext{
* Corresponding author: 44103044@qq.com.
} 
$398 \mathrm{~kg} / \mathrm{m} 3$, the water consumption was $163 \mathrm{~kg} / \mathrm{m} 3$, the water-binder ratio was 0.41 , and the sand ratio was 45. $\%$, silica fume content was designed to be $0 \%, 4 \%$,
$6 \%, 8 \%, 10 \%$ and $12 \%$. The specific test mix numbers and corresponding concrete mix ratios were shown in Table 3 .

Table 1 Physical properties of $\mathrm{P} \cdot \mathrm{O} 42.5$ cement

\begin{tabular}{|c|c|c|c|c|c|c|c|}
\hline \multirow{2}{*}{$\begin{array}{c}\text { Specific surface } \\
\text { area }\left(\mathrm{m}^{2} / \mathrm{kg}\right)\end{array}$} & \multirow{2}{*}{$\begin{array}{c}\text { Standard } \\
\text { consistency } \%)\end{array}$} & \multicolumn{2}{|c|}{ Setting time (min) } & \multicolumn{2}{|c|}{ Compressive strength (Mpa) } & \multicolumn{2}{|c|}{$\begin{array}{c}\text { Flexural strength } \\
\text { (MPa) }\end{array}$} \\
\cline { 3 - 8 } & & Initial setting & Final setting & $3 \mathrm{~d}$ & $28 \mathrm{~d}$ & $3 \mathrm{~d}$ & $28 \mathrm{~d}$ \\
\hline 315 & 25.7 & 175 & 310 & 30.2 & 51.3 & 4.3 & 8.1 \\
\hline
\end{tabular}

Table 2 Technical indicators of mid-weathered phonolite in Kenya

\begin{tabular}{|c|c|c|c|c|c|}
\hline Technical indicators & $\begin{array}{c}\text { Crush value } \\
(\%)\end{array}$ & $\begin{array}{c}\text { Los Angeles wear } \\
\text { rate }(\%)\end{array}$ & $\begin{array}{c}\text { Apparent density } \\
\left(\mathrm{kg} / \mathrm{m}^{3}\right)\end{array}$ & $\begin{array}{c}\text { Water absorption } \\
(\%)\end{array}$ & $\begin{array}{c}\text { Robustness } \\
(\%)\end{array}$ \\
\hline Testing results & 21.6 & 24.1 & 2668 & 2.2 & 12.8 \\
\hline
\end{tabular}

Table 3 Mix proportion of concrete sample

\begin{tabular}{|c|c|c|c|c|c|c|c|}
\hline Sample & $\begin{array}{c}\text { Cement } \\
\left(\mathrm{kg} / \mathrm{m}^{3}\right)\end{array}$ & $\begin{array}{c}\text { Fly ash } \\
\left(\mathrm{kg} / \mathrm{m}^{3}\right)\end{array}$ & $\begin{array}{c}\text { Silica fume } \\
\left(\mathrm{kg} / \mathrm{m}^{3}\right)\end{array}$ & $\begin{array}{c}\text { Silica fume } \\
\text { content }(\%)\end{array}$ & $\begin{array}{c}\text { Fine aggregate } \\
\left(\mathrm{kg} / \mathrm{m}^{3}\right)\end{array}$ & $\begin{array}{c}\text { Coarse aggregate } \\
\left(\mathrm{kg} / \mathrm{m}^{3}\right)\end{array}$ & $\begin{array}{c}\text { Water } \\
\left(\mathrm{kg} / \mathrm{m}^{3}\right)\end{array}$ \\
\hline G0 & 318 & 80 & 0 & 0 & 824 & 1025 & 163 \\
\hline G4 & 318 & 64 & 16 & 4 & 824 & 1025 & 163 \\
\hline G6 & 318 & 56 & 24 & 6 & 824 & 1025 & 163 \\
\hline G8 & 318 & 48 & 32 & 8 & 824 & 1025 & 163 \\
\hline G10 & 318 & 40 & 40 & 10 & 824 & 1025 & 163 \\
\hline G12 & 318 & 32 & 48 & 12 & 824 & 1025 & 163 \\
\hline
\end{tabular}

\subsection{Testing methods}

The airtightness of concrete was tested in accordance with Standard for Acceptance of Concrete Works in Railway TB10424-2018 and carried out under constant air pressure. The size of the test piece was a round table with an upper diameter of $175 \mathrm{~mm}$, a lower diameter of $185 \mathrm{~mm}$, and a height of $150 \mathrm{~mm}$. After removing the mold, the samples were cured in a standard curing room for 28 days and continued to air dry for 14-28 days. When the humidity of the specimen was balanced with the atmosphere, the air permeability test can be carried out by the lower air inlet method or the upper air inlet method. The air inlet pressure was $0.3 \mathrm{MPa}$ and $0.6 \mathrm{MPa}$. After the voltage was stabilized, the air permeability was read and use to calculate the concrete air permeability coefficient.

According to Standard for Test Methods of LongTerm Performance and Durability of Ordinary Concrete GB/T50082-2009, the dry wet cycle sulfate erosion test was carried out on the samples. After forming, one part of the concrete was put into the dry wet cycle sulfate erosion testing machine for dry wet cycle test, and the other part was put into the standard curing room for standard curing. When the concrete dry wet cycle reached 150 times, the compressive strength of concrete under two environments was tested respectively, and the ratio of the strength of concrete under dry-wet cycles to the strength of the marked-cured concrete was taken as the anti-corrosion coefficient.

The test of compressive strength of concrete was conducted in consonance with Standard for Test Method of Mechanical Properties on Ordinary Concrete GB 50081-2019.

\section{Results and discussion}

\subsection{Influence of silica fume on the workability of concrete}

The work performance of concrete is very important to the construction quality of concrete, and it determines the construction quality of concrete to a certain extent. If the work performance of concrete is good, the construction is relatively easy, and the requirements for workers are low, and the construction intensity of workers is low, which is easy to improve the quality of concrete construction. If the work performance of concrete is poor, on the one hand, the construction is difficult, and workers are easy to slack off. On the other hand, to improve the difficulty of construction, illegal water addition is likely to occur, which will further cause a high risk of construction quality.

For this reason, the experiment researched the influence of silica fume on the working performance of moderate weathered phonolite concrete. The test results were shown in Table 4 . It can be seen that with the increase of silica fume content, the performance of concrete showed a downward trend, except for the addition of silica fume. At $4 \%$, the work performance of concrete changed little, and the content of other silica fume increased, and the decline of concrete work performance was more obvious. In terms of slump, the initial slump of the benchmark concrete was $205 \mathrm{~mm}$. When the content of silica fume was $4 \%$, the initial slump was consistent with the benchmark concrete. 
When the content of silica fume was increased to $6 \%$, $8 \%, 10 \%$, and $12 \%$, the slump of the concrete decreases by $7.3 \%, 14.6 \%, 29.3 \%$, and $36.6 \%$, respectively, compared with the benchmark concrete. The change law of concrete expansion and air content with the increase of silica fume content was similar to that of concrete slump, and both showed a downward trend with the increase of silica fume content.

The fluidity loss of concrete was relatively obvious over time. The standard concrete slump loss $5 \mathrm{~mm}$ after $1 \mathrm{~h}$, the expansion loss was $15 \mathrm{~mm}$, and the test group G4 with $4 \%$ silica fume content loss $15 \mathrm{~mm}$ after $1 \mathrm{~h}$. The expansion loss was $20 \mathrm{~mm}$. It can be seen that after adding silica fume, the performance of the concrete will be more lost over time. The test groups G10 and G12 with higher silica fume content had a smaller initial slump of the concrete. After $1 \mathrm{~h}$, The concrete had shown a dry and hard state.

The main reason for the influence of silica fume on the performance of concrete was that on the one hand, the particle size of silica fume is small, and the same mass can replace fly ash to obtain more slurry, which has a beneficial effect on the performance of concrete; on the other hand, the particles silica fume with a smaller particle size can fill the pores between cement and fly ash particles, start a certain water reducing effect, and improve the performance of concrete. However, it is also because the particle size of silica fume is too small, the specific surface area is large, and usually has a large water demand. This effect reduced the working performance of the concrete. When silica fume was mixed into concrete at a low content, the negative impact of silica fume on the performance of concrete was still small, and the performance of concrete did not change much, and when the content of silica fume was high, it had a negative impact on the performance of concrete. The impact has become prominent, and the performance of concrete has decreased significantly. From the above research, it can be known that when using silica fume to prepare airtight concrete, the dosage should not be too high.

Table 4 The influence of silica fume on the performance of moderately weathered phonolite concrete

\begin{tabular}{|c|c|c|c|c|c|c|}
\hline \multirow{2}{*}{ Sample } & \multicolumn{3}{|c|}{ Initial moment } & \multicolumn{2}{c|}{ After 1h } \\
\cline { 2 - 7 } & Slump (mm) & Slump flow (mm) & Air content (\%) & Slump (mm) & Slump flow (mm) & Air content (\%) \\
\hline G0 & 205 & 510 & 3.1 & 200 & 495 & 2.6 \\
\hline G4 & 205 & 490 & 3.2 & 190 & 470 & 2.8 \\
\hline G6 & 190 & 450 & 2.6 & 180 & 430 & 2.3 \\
\hline G8 & 175 & 400 & 2.2 & 165 & - & 1.7 \\
\hline G10 & 145 & - & 2.1 & - & - & - \\
\hline G12 & 130 & - & 1.7 & - & - & - \\
\hline
\end{tabular}

\subsection{Influence of silica fume on the compressive strength of concrete}

Compressive strength is the most basic technical index of concrete, and it is also the most important technical index as a structural material. For this reason, the influence of different dosages of silica fume on the compressive strength of concrete was tested. The test results were shown in Fig. 1. It can be seen that with the increase of the amount of silica fume, the compressive strength of the moderately weathered phonolite concrete increased first and reached the highest when the amount of silica fume was $8 \%$, and then gradually decreased.

At the $7 \mathrm{~d}$, the compressive strength of the benchmark concrete with a silica fume content of $0 \%$ was $29.7 \mathrm{MPa}$, and the test groups G4, G6, G8, and G8 with a silica fume content of $4 \%, 6 \%, 8 \%, 10 \%$, and $12 \% \mathrm{G} 10$ and G12 were respectively $12.5 \%, 20.2 \%, 27.3 \%, 21.5 \%$ and $15.5 \%$ higher than the compressive strength of the benchmark concrete. At $28 \mathrm{~d}$, the compressive strength of reference concrete with $0 \%$ silica fume was $43.6 \mathrm{MPa}$, and the compressive strength of G4, G6, G8, G10 and G12 with $4 \%, 6 \%, 8 \%, 10 \%$ and $12 \%$ silica fume were $4.6 \%, 8.3 \%, 10.3 \%, 6.7 \%$ and $3.9 \%$ higher than that of reference concrete respectively.

The reason why the compressive strength of moderately weathered phonolite concrete first increased and then decreased with the increase of silica fume may be that the silica fume particle size is small, which can well fill the pores between relatively coarse particles such as cement and fly ash in concrete, so as to improve the compactness of concrete and the compressive strength of concrete. On the other hand, silica fume has certain pozzolanic activity in the alkaline environment of cement hydration, its secondary hydration reaction can occur to further improve the compressive strength of concrete. However, due to the large water demand of silica fume, when the silica fume content was too large, the higher water demand increased the viscosity and the forming difficulty of concrete, and then the compactness of concrete became poor during the forming process, which made the improvement trend of concrete compressive strength decrease.

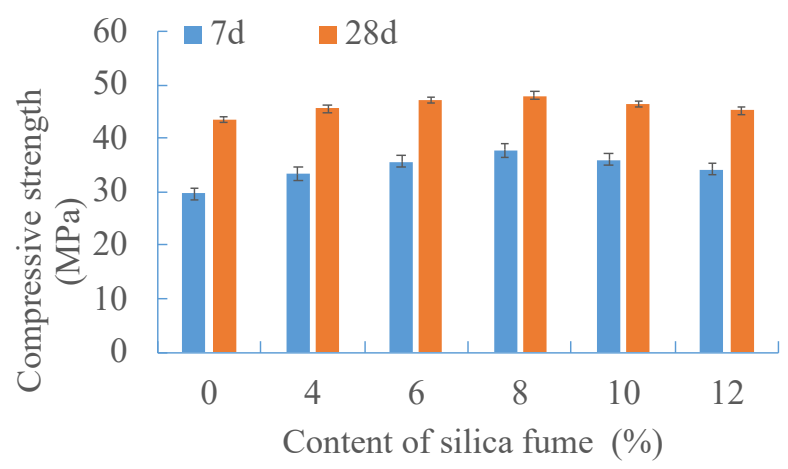

Fig. 1 Effect of silica fume on compressive strength of concrete 


\subsection{Influence of silica fume on the corrosion resistance coefficient of concrete}

In addition to the working performance and mechanical properties, the durability of moderately weathered phonolite concrete is also very important, such as dry wet cycle, sulfate erosion, chloride ion erosion, freezethaw damage of concrete and other factors. Therefore, in addition to considering the working performance and mechanical properties to meet the design requirements, the durability of moderately weathered phonolite concrete needs to be studied.

Concrete durability refers to the ability of concrete to resist the action of environmental media and maintain its good performance for a long time, so as to maintain the safety and normal use of concrete structure. It usually includes salt crystal erosion, steel corrosion, concrete carbonation, freeze-thaw damage and so on. The influence of silica fume on the durability of concrete was studied by using dry wet cycle sulfate attack as a representative.

The influence of silica fume content on the corrosion resistance coefficient of concrete was shown in Fig. 2. From the test results in the figure, it can be seen that with the increase of silica fume content, the corrosion resistance coefficient of concrete first gradually increased, and then presented a downward trend. The corrosion resistance coefficient of concrete with $12 \%$ silica fume content was basically close to that of benchmark concrete. The corrosion resistance coefficients of G0, G4, G6, G8, G10 and G12 with $0 \%$, $4 \%, 6 \%, 8 \%, 10 \%$ and $12 \%$ silica fume were $76.1 \%$, $85.3 \%, 89.2 \%, 81.3 \%, 79.8 \%$ and $77.6 \%$ respectively. It can be seen that the corrosion resistance coefficient of concrete with $6 \%$ silica fume was the highest, and the resistance to wet and dry cyclic sulfate was the best. The corrosion resistance coefficients of concrete with $10 \%$ and $12 \%$ silica fume were close to those of reference concrete without silica fume. The effect of high content of silica fume on the resistance of concrete to dry wet cycle sulfate attack was small.

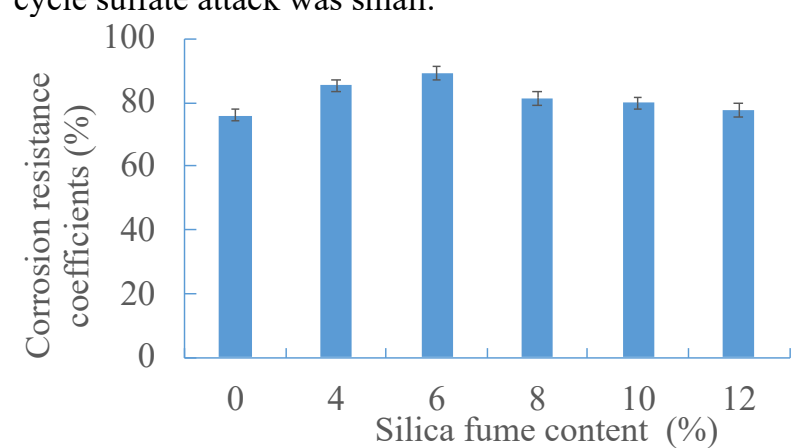

Fig 2 Influence of silica fume on the corrosion resistance coefficient of concrete

\subsection{Influence of silica fume on the airtightness of concrete}

The test results of the influence of silica fume content on the airtightness of concrete were shown in Fig. 3. It can be seen from the figure that with the increase of the amount of silica fume, the air permeability coefficient of concrete was significantly reduced, and the airtightness of concrete was significantly improved.

The air permeability coefficient of the benchmark concrete with a silica fume content of $0 \%$ was $1.825 \times 10^{-}$ ${ }^{12} \mathrm{~cm} / \mathrm{s}$, and the air permeability coefficients of G4, G6, $\mathrm{G} 8, \mathrm{G} 10$, and G12 samples were $1.12,1.01,0.355,0.238$, $0.105 \times 10^{-12} \mathrm{~cm} / \mathrm{s}$, respectively.

When the content of silica fume exceeded $8 \%$, the air permeability coefficient of concrete decreases exponentially. The reason why silica fume can well reduce the air permeability coefficient of concrete and improve the airtightness of concrete may be due to the extremely fine particle size and large specific surface area of silica fume. Although the content of silica fume was relatively small, the amount of particles mixed was very large, so it can fill the pores between cement and fly ash particles, reduce the pore size and improve the gas compactness. In addition, silica fume, fly ash or slag powder are all artificial pozzolanic materials, which all have a pozzolanic effect. The pozzolanic effect of silica fume is more significant than that of fly ash, with higher hydration activity, more hydration products, and greater contribution to the gas compactness of concrete.

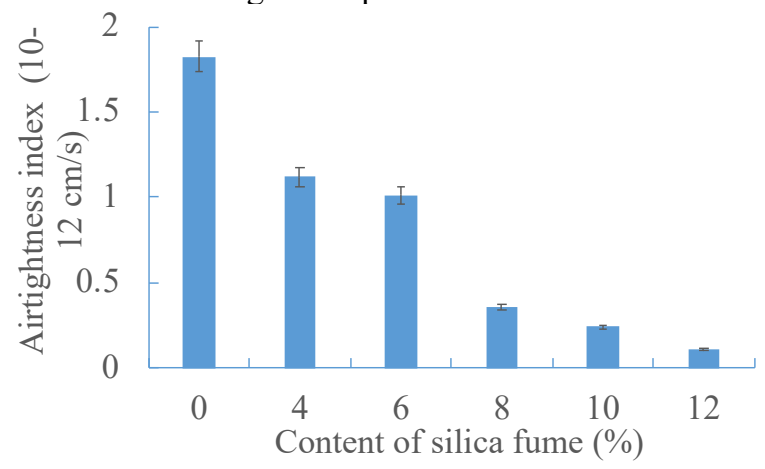

Fig. 3 Influence of silica fume on the airtightness of concrete

\section{Conclusions}

In view of the widespread existence of moderately weathered phonolite around the Nairobi expressway project in Kenya, which has certain adverse effects on the performance of concrete, this paper studied the effect of adding silica fume to improve the performance of concrete and promote the application of moderately weathered phonolite in concrete. The results were as follows:

(1) With the increase of silica fume content, the workability of concrete showed a downward trend. Except for $4 \%$ silica fume content, the change of concrete workability was small, and the decline trend of concrete workability was obvious with the increase of other silica fume content. The compressive strength of airtightness concrete increased at first and reached the highest when the silica fume content is $8 \%$, and then decreased gradually.

(2) With the increase of silica fume content, the anticorrosion coefficient of concrete increased first and then decreased. With the increase of silica fume content, the permeability coefficient of concrete decreased significantly, and the airtightness of concrete increased significantly. 
(3) Considering the working performance, mechanical properties, durability and air tightness test results of moderately weathered phonolite concrete, silica fume can be used to prepare moderately weathered phonolite concrete in the project, and the content of silica fume was recommended to be controlled at $4 \%-8 \%$.

\section{References}

1. C. Dong and Y. Wan, World Build. Mater. 42, 25 (2021).

2. Z. Ma, X. Wen, Y. Xiao, X. Lei, and H. Guo, Water Resour. Hydropower Northeast China 37, 51 (2019).

3. Y. Zhao, Y. Zhang, J. Xia, Y. Zhou, and K. Li, World Build. Mater. 39, 9 (2018).

4. Z. Li, P. Guo, J. Xia, Y. Zhou, Y. He, and K. Li, Subgrade Eng. 121 (2018).
5. Z. Li, X. Meng, Y. Zhou, J. Xia, H. Chen, and K. Li, Concrete 95 (2018).

6. P. Bai, Y. Zhang, and C. Zhu, New Build. Mater. 45, $5(2018)$

7. X. Wen, Y. Lei, J. Xia, Y. Zhou, and K. Li, New Build. Mater. 44, 126 (2017).

8. C. Guo, C. Chen, Q. Zou, C. Zhu, G. Wang, and Z. Sun, China Concr. Cem. Prod. 27 (2017).

9. S. Ding, J. Liang, J. Xia, Y. Zhou, B. Gao, and K. Li, World Build. Mater. 38, 16 (2017).

10. D. Qu, K. Li, J. Xia, Y. Zhou, and Y. Wang, New Build. Mater. 44, 91 (2017).

11. K. Li, B. Zhang, D. Yang, L. Xiao, J. Xia, and Y. Zhou, Subgrade Eng. 114 (2016).

12. Z. Cui and J. Li, Bull. Chin. Ceram. Soc. 35, 2396 (2016). 